\title{
AKTIVASI NILAI PENDIDIKAN DALAM KONSEP ASWAJA
}

\section{ZAITUR RAHEM}

\author{
(STIT Aqidah Usymuni Sumenep) \\ Email: zaitur_rahem@yahoo.co.id
}

\begin{abstract}
Education in Indonesia is like being in a tangled yarn winding. Growth is lush yet full of mud and moss. There is a happy face, but there was an air-rada rada black. Simply put, our education (Indonesia) like a ship sailing aimlessly and goals. Appeared later than this confusion about the various interpretations of education in Indonesia. Such as Character Education, Cultural Value-Based Education, Social, Religious and others. The times, the movement of ideas and seek solutions to the problems of education in Indonesia continues to grow. A number of researchers, experts and practitioners work together to look for the hallmark of education in Indonesia. Various methods and stratgei done in order to find distinctive character education formulations ness. There are various kinds of character education are taken from the values of both groups, a particular doctrine or custom. This new discovery is the responsibility of the observer forms, practitioners and education experts on wajahpendidikan in Indonesia. One of these ideas Aswaja Value-Based Character Education. Is this keaswajaan effective and could be part of the establishment of the nation's private good?
\end{abstract}

\begin{abstract}
Abstrak
Dunia pendidikan di Indonesia ibarat berada dalam lilitan benang kusut. Pertumbuhannya subur namun penuh lumpur dan lumut. Ada wajah gembira, namun ada suasana rada-rada hitam. Sederhananya, pendidikan kita (Indonesia) ibarat kapal berlayar tak tentu arah dan tujuan. Muncul kemudian dari kekalutan ini aneka tafsir tentang pendidikan Indonesia. Semisal Pendidikan Karakter, Pendidikan Berbasis Nilai Budaya, Sosial, Agama dan lainnya. Seirig perkembangan zaman, ide dan gerakan mencari solusi masalah pendidikan di Indonesia terus tumbuh berkembang. Sejumlah peneliti, pakar dan praktisi pendidikan bahu membahu mencari ciri khas pendidikan di Indonesia. Berbagai macam metode dan stratgei dilakukan dalam rangka mencari formulasi pendidikan berkarakter khas ke-Indonesia-an. Ada berbagai macam pendidikan karakter yang diambil dari nilai-nilai baik kelompok, ajaran atau adat tertentu. Penemuan baru ini merupakan bentuk tanggungjawab para pemerhati, praktisi dan pakar pendidikan atas wajah pendidikan di Indonesia. Salah satunya ide Pendidikan Karakter Berbasis Nilai ASWAJA.
\end{abstract}


Apakah nilai keaswajaan ini efektif dan bisa menjadi bagian dari pembentukan pribadi bangsa yang baik?

Kata Kunci: Pendidikan, Karakter dan ASWAJA

\section{Pendahuluan}

Pendidikan berakarakter di Indonesia terus dihidupkan. Di berbagai forum ilmiah, para pakar pendidikan mecari formasi baru, reinovasi, reaktuliasi tentang sebuah konsep pendidikan yang memmiliki karakter dari kehidupan bangsa Indonesia. Kehidupan dalam batasan ini adalah sebuah aktifitas (internal dan eksternal) kemanusiaan manusia Indonesia. Menemukan dan meramu pendidikan berkarakter ini salah satu bukti hidupnya tradisi ilmiah di tengah-tengah bangsa Indonesia, khususnya para praktisi pendidikan. Fokus kajian ini adalah reintegerasi pendidikan dari sebuah konsep yang berafiliasi dengan aktifitas kehidupan sebagian bangsa Indonesia. Yaitu, aktivasi nilai pendidikan dalam konsep Ahlus as-Sunnah Wal Jamaah untuk menjadi karakter pendidikan di Indonesia.

Karakter ${ }^{1}$ dalam beberapa tahun terakhir menjadi bahan perbincangan di semua forum kajian. Baik kajian ilmiah atau kajian lepas para praktisi dan pemerhati pendidikan. Topik tentang pendidikan karakter, semakin lama didiskusikan kian tidak ada puncak kesimpulan. Pendidikan karakter menjadi tema 'panas-dingin' yang sepertinya sulit dpecahkan. Apakah para praktisi dan pemerhati pendidikan kita mulai habis nalar kecerdasannya? Persoalannya bukan karena cerdas atau tidak. Tetapi, pendidikan karakter menjadi semacam topik menarik sekaligus menggelisahkan. Sebab, pertanyaan yang sering muncul di benak, mengapa topik pendidikan karakter baru memuncak di era saat ini?

Pendidikan karakter, penulis yakini sudah ada sejak negeri ini ada. Indonesia, dalam rilisan sejarah wilayah yang kaya akan aneka kebudayaan. Kultur dan ciri khas sosial kemasyarakatan dalam bingkai NKRI ini menjadi ajuan karakater bangsa. Pendidikan karakter di Indonesia, sekilas menjadi isu sentral di tengah kondisi bangsa yang kacau. Meski tidak dimunculkan sebagai topik utama, pendidikan karakter ini sudah mengiringi perjalanan bangsa ini.

Pendidikan karakter dalam sudut pandang global diartikan sebagai pendidikan berbasis karakter. Karakter sendiri dalam kamus diartikan sifat-sifat kejiwaan akhlak atau budi pekerti yang membedakan seorang diri dengan yang lain². Sementara pendidikan karakter yang diperbicangkan dewasa ini mengacu pada pendidikan Indonesia yang memiliki karakter khas keindonesiaan. Jika pendidikan karakter dalam cakupannya masih luas, maka pendidikan karakter yang diperbincangkan saat ini memerlukan penafsiran terus menerus. Setidaknya,

1 Doni Kusuma A, Pendidikan Karakter, (Jakarta: PT Grasindo, 2009), 146. Lihat juga Wina Sanjaya, Pembelajaran dalam Implementasi Kurikulum Berbasis Kompetensi (Jakarta: Kencana, 2006), 141.

2 Departemen Pendidikan Nasional, Kamus Besar bahasa Indonesia Edisi Keempat, (Jakarta: Departemen Pendidikan Nasional, 2008), 623. 
perbicangan-perbincangan tentang pendidikan karakter saat ini masih dalam tahapan dasar. Sebab, hasil yang diinginkan dari pendidikan karakter belum sepenuhnya berhasil. Terbukti, saat beberapa tahun lalu gencar-gencarnya penerapan pendidikan karakter, aneka kebrutalan oknum dari pendidikan semakin meningkat. Situasi ini memang bukan menjadi kesimpulan akhir. karena, manfaat dari penerapan pendikan karakter ini sedikit banyak berpengaruh terhadap kepribadian anak didik. ${ }^{3}$

Pendidikan karakter dalam kondisi ini masih elastis untuk dilaksanakan. Dalam takaran praktis pendidikan karakter ini bisa dikuak dari semua nilai-nilai luhur ajaran (agama dan adat istiadat), termasuk nilai-nilai dari faham ahlussunnah wal jamaah yang di dalamnya terdapat nilai luhur. Seperti amar ma'ruf nahi mungkar, adil dan elegan (ta'adul dan tawassuth), toleran (tasamuh), dan seimbang (tawazun). Target dari pendidikan karakter berbasis nilai-nilai faham ASWAJA ini untuk mencetak pribadi yang berbudi luhur (ber-akhlak al karimah) dan bermanfaat untuk semua (khairunnas anfa'uhum linnaas).

\section{Pendidikan Karakter Selama Ini}

Pendidikan karakter di Indonesia yang diperbicangkan selama ini mengacu pada nilai karakter dan budaya bangsa Indonesia. Pada prinsipnya, karakter sebagai suatu moral excellence atau akhlak dibangun di atas berbagai kebajikan (virtues) yang pada gilirannya hanya memiliki makna ketika dilandasi atas nilainilai yang berlaku dalam budaya (bangsa). Karakter bangsa Indonesia adalah karakter yang dimiliki warga Negara Indonesia berdasarkan tindakan-tindakan yang dinilai sebagai suatu kebajikan berdasarkan nilai yang berlaku di masyarakat dan bangsa Indonesia.

Oleh karena itu, Pendidikan Karakter selama ini diarahkan pada upaya mengembangkan nilai nilai luhur pancasila. Berbeda dari materi ajar yang bersifat mastery, sebagaimana halnya suatu performance content suatu kompetensi, materi Pendidikan Budaya dan Karakter Bangsa selama ini bersifat developmental. Perbedaan hakikat kedua kelompok materi ini mengidealkan pelaksanaan yag berbeda dalam proses pendidikan. Materi pendidikan yang bersifat developmental menghendaki proses pendidikan yang cukup panjang dan bersifat saling menguat (reinforce) antara kegiatan belajar dengan kegiatan belajar lainnya, antara proses belajar di kelas dengan kegiatan kurikuler di sekolah dan di luar sekolah.

Keseimbangan penerapan pendidikan karakter antara di dalam kelas dan di luar ini akan mampu menghasilkan tujuan yang diharapkan. Penerapan pendidikan karakter ini tidak akan bermakna tanpa ada kegiatan kongkrit. Pendidikan karakter, sekali lagi lebih menekankan pada praktek riil yang mengacu pada pembentukan watak individual (anak didik).

Disamping persamaan dalam kelompok, materi belajar ranah pengetahuan (cognitive) yang dalam satu kelompok developmental dengan nilai, antara

${ }^{3}$ Lihat juga Mortimer J. Adler, Philosophies Of Education, (Chicago: Uiversity Chicago Press, 1962), 209. 
keduanya terdapat perbedaan yang mendasar dalam perencanaan pada dokumen kurikulum (KTSP), silabus, RPP, dan proses belajar. Materi belajar ranah pengetahuan dapat dijadikan pokok bahasan, sedangkan materi nilai dalam Pendidikan Budaya dan Karakter Bangsa tidak dapat dijadikan pokok bahasan karena mengandung resiko akan menjadi materi yang bersifat kognitif.

Oleh karena itu, dalam pengembangan materi Pendidikan Budaya dan Karakter Bangsa sikap menyukai, ingin memiliki, dan mau menjadikan nilai-nilai tersebut sebagai dasar bagi tindakan dalam perilaku kehidupan peserta didik sehari-hari merupakan persyaratan awal yang mutlak untuk keberhasilan Pendidikan Karakter.

Penerapan dari pendidikan karakter ini berdasarkan Undang-Undang Republik Indonesia nomor 20 tahun 2003 tentang Sistem Pendidikan Nasional (UU Sisdiknas) merumuskan fungsi dan tujuan pendidikan nasional yang harus digunakan dalam mengembangkan upaya pendidikan di Indonesia. Pasal 3 UU Sisdiknas menyebutkan, "Pendidikan nasional berfungsi mengembangkan dan membentuk watak serta peradaban bangsa yang bermartabat dalam rangka mencerdaskan kehidupan bangsa, bertujuan untuk berkembangnya potensi peserta didik agar menjadi manusia yang beriman dan bertakwa kepada Tuhan Yang Maha Esa, berakhlak mulia, sehat, berilmu, cakap, kreatif, mandiri, dan menjadi warga negara yang demokratis serta bertanggung jawab".

Tujuan pendidikan nasional itu merupakan rumusan mengenai kualitas manusia Indonesia yang harus dikembangkan oleh setiap satuan pendidikan. Oleh karena itu, rumusan tujuan pendidikan nasional menjadi dasar dalam pengembangan pendidikan budaya dan karakter bangsa.

Kehadiran pendidikan karakter ini muncul bersamaan dengan sejumput persoalan (sebut saja) penyakit sosial. Seperti maraknya tindak pidana korupsi, pencurian, seks bebas di kalangan remaja, dan tindakan amoral yang lain. Geliat dari pendidikan karakter ini ada hakekatnya sumbu awal memacu para pelaku pendidikan bisa membenahi dunia pendidikan.

Pendidikan tidak hanya dianggap sebagai proses. Nasution menganggap proses dalam makna pendidikan bersifat global. Jadi, pesoalan proses ini mengacu pada gerakan kongkrit untuk memaksimalkan peran dari pendidikan. Proses bisa dimaknai sebagai tindakan mengubah cara pandang, dan cara berpikir anak didik kepada hal yang lebih positif. Pendidikan karakter, menurut Miller (1985) dianggap salah satu jalan menumbuhkan sikap positif dalam diri anak didik. Di Indonesia, pendidikan karakter yag sedang digalakkan adalah pendidikan karakter budaya dalam perspektif bangsa Indonesia.

Landasan Pedagogis Pendidikan Budaya dan Karakter Bangsa Pendidikan adalah suatu upaya sadar untuk mengembangkan potensi peserta didik secara optimal. Usaha sadar itu tidak boleh dilepaskan dari lingkungan peserta didik berada, terutama dari lingkungan budayanya, karena peserta didik hidup tak terpishkandalam lingkungannya dan bertindak sesuai dengan kaidah-kaidah budayanya. Pendidikan yang tidak dilandasi oleh prinsip itu akan menyebabkan peserta didik tercerabut dari akar budayanya. Ketika hal ini terjadi, maka mereka tidak akan mengenal budayanya dengan baik sehingga ia menjadi orang "asing" 
dalam lingkungan budayanya. Selain menjadi orang asing, yang lebih mengkhawatirkan adalah dia menjadi orang yang tidak menyukai budayanya.

Budaya, yang menyebabkan peserta didik tumbuh dan berkembang, dimulai dari budaya di lingkungan terdekat (kampung, RT, RW dan desa) berkembang ke lingkungan yang lebih luas yaitu budaya nasional bangsa dan budaya universal yang dianut oleh ummat manusia. Apabila peserta didik menjadi asing dari budaya terdekat maka dia tidak mengenal dengan baik budaya bangsa dan dia tidak mengenal dirinya sebagai anggota budaya bangsa. Dalam situasi demikian, dia sangat rentan terhadap pengaruh budaya luar dan bahkan cenderung untuk menerima budaya luar tanpa proses pertimbangan (valueing). Kecenderungan itu terjadi karena dia tidak memiliki norma dan nilai budaya nasionalnya yang dapat digunakan sebagai dasar untuk melakukan pertimbangan (valueing).

Semakin kuat seseorang memiliki dasar pertimbangan, semakin kuat pula kecenderungan untuk tumbuh dan berkembang menjadi warga negara yang baik. Pada titik kulminasinya, norma dan nilai budaya secara kolektif pada tingkat makro akan menjadi norma dan nilai budaya bangsa. Dengan demikian, peserta didik akan menjadi warga negara Indonesia yang memiliki wawasan, cara berpikir, cara bertindak, dan cara menyelesaikan masalah sesuai dengan norma dan nilai ciri ke-Indonesia-annya.

Hal ini sesuai dengan fungsi utama pendidikan yang diamanatkan dalam UU Sisdiknas," mengembangkan kemampuan dan membentuk watak serta peradaban bangsa yang bermartabat dalam rangka mencerdaskan kehidupan bangsa". Oleh karena itu, aturan dasar yang mengatur pendidikan nasional (UUD 1945 dan UU Sisdiknas) sudah memberikan landasan yang kokoh untuk mengembangkan keseluruhan potensi diri seseorang sebagai anggota masyarakat dan bangsa.

Pendidikan adalah suatu proses enkulturasi, berfungsi mewariskan nilai-nilai dan prestasi masa lalu ke generasi mendatang. Nilai-nilai dan prestasi itu merupakan kebanggaan bangsa dan menjadikan bangsa itu dikenal oleh bangsabangsa lain. Selain mewariskan, pendidikan juga memiliki fungsi untuk mengembangkan nilai-nilai budaya dan prestasi masa lalu itu menjadi nilai-nilai budaya bangsa yang sesuai dengan kehidupan masa kini dan masa yang akan datang, serta mengembangkan prestasi baru yang menjadi karakter baru bangsa. Oleh karena itu, pendidikan budaya dan karakter bangsa merupakan inti dari suatu proses pendidikan.

Proses pengembangan nilai-nilai yang menjadi landasan dari karakter itu menghendaki suatu proses yang berkelanjutan, dilakukan melalui berbagai mata pelajaran yang ada dalam kurikulum (kewarganegaraan, sejarah, geografi, ekonomi, sosiologi, antropologi, bahasa Indonesia, IPS, IPA, matematika, agama, pendidikan jasmani dan olah raga, seni, serta ketrampilan). Dalam mengembangkan pendidikan karakter bangsa, kesadaran akan siapa dirinya dan bangsanya adalah bagian yang teramat penting.

Kesadaran tersebut hanya dapat terbangun dengan baik melalui sejarah yang memberikan pencerahan dan penjelasan mengenai siapa diri bangsanya di masa lalu yang menghasilkan dirinya dan bangsanya di masa kini. Selain itu, pendidikan harus membangun pula kesadaran, pengetahuan, wawasan, dan nilai 
berkenaan dengan lingkungan tempat diri dan bangsanya hidup (geografi), nilai yang hidup di masyarakat (antropologi), sistem sosial yang berlaku dan sedang berkembang (sosiologi), sistem ketatanegaraan, pemerintahan, dan politik (ketatanegaraan/politik/kewarganegaraan), bahasa Indonesia dengan cara berpikirnya, kehidupan perekonomian, ilmu, teknologi, dan seni. Terobosan memasukkan nilai-nilai luhur budaya bangsa ini akan mampu memproses karakter anak didik sesuai dengan harapan 4 .

Pendidikan budaya dan karakter bangsa dilakukan melalui pendidikan nilainilai atau kebajikan yang menjadi nilai dasar budaya dan karakter bangsa. Kebajikan yang menjadi atribut suatu karakter pada dasarnya adalah nilai. Oleh karena itu pendidikan budaya dan karakter bangsa pada dasarnya adalah pengembangan nilai-nilai yang berasal dari pandangan hidup atau ideologi bangsa Indonesia, agama, budaya, dan nilai-nilai yang terumuskan dalam tujuan pendidikan nasional. ${ }^{5}$

Pendidikan karakter menjadi ciri khas dari sebuah komunitas terdidik. Pada tataran ini pendidikan karakter bisa dimasuki aneka macam kekhasan budaya dan ajaran yang baik. Nilai-nilai faham Ahlussunnah Wal Jamaah yang didalamnya memuat nilai-nilai positif bisa menjadi bagian dari pengembangan pendidikan karakter ini.

\section{Menuju Pendidikan Indonesia Berkarakter ASWAJA}

Ahalussunnah Wal Jamaah atau sering diakronimkan dengan ASWAJA. Faham ASWAJA sederhananya adalah faham yang memuat nilai ajaran Al Qur'an dan Hadis. Hadis disini adalah perbuatan yang dicontohkan oleh Nabi Muhammad Saw. Perbuatan Nabi adalah akhlak al karimah/sopan santun. Ahlussunnah Wal Jamaah dalam prinsipnya ingin menciptakan tatanan kehidupan yang sopan santun. Misi luhur ini menjadi ruh untuk mengaktualiasinya dalam bingkai pendidikan praktis dalam upaya mencetak generasi bangsa yang berbudi luhur.

Salah satu nilai dari ajaran Ahlussunnah Wal Jamaah ini adalah akhlak al karimah. Akhlakul karimah memuat unsur konsiderasi yang dominan dalam rangka pembentukan karakter individual. Sebab dalam bangunan akhlak al karimah ini memuat sejumlah poin penting yaitu; adil dan elegan (ta'adul dan tawassuth), toleran (tasamuh), seimbang (tawazun) dan amar ma' ruf nahi mungkar. ${ }^{6}$

Unsur-unsur ini adalah banguan poin yang berkelindan satu sama lain kesemua unsur di atas ini saling berkaitan erat dan tidak bisa dihilangkan. Sebab, bangunan unsur ini mengantarkan individu yang berjalan di garis ini menemukan ke-aswaja-annya. ${ }^{7}$

${ }^{4}$ Charlene Tan, Philosopical Reflections For Education, Chapter I, Philosophers on Edication (London: Institute of Education University of London, ), 3 .

5 Disarikan dari materi pelatihan pendidikan budaya dan Karakter bangsa Kementerian Pendidikan Nasional, Badan Penelitian dan Pengembangan Pusat Kurikulum.

${ }^{6}$ Abdul Muchid Muzadi, Mengenal Nahdlatul Ulama, (Surabaya: Khalista, 2006), 27.

7 Hairus Salim HS dan Muhammad Ridwan, Kultur Hibrida Anak Muda NU di Jalur Kultural (Bunga Rampai), (Yogyakarta: LKiS, 1999), 
Pada wilayah pendidikan, dalam perbincangan pendidikan karakter ini unsur keaswajaan dalam cakupan yang lain bisa menjadi objek dalam pengembangan pendidikan karakter. Seperti dimaksud dalam tujuan pendidikan nasional, maka hakikatnya pendidikan upaya pembentukan karakter individu berbudi luhur. Dalam perspektif keaswajaan maka pedidikan karakter ASWAJA adalah pendidikan yang memuat unsur keaswajaan.

Karakter keaswajaan ini pada prinsipnya bisa menjadi frame mencetak pribadi yang aswaja secara utuh. Pendidikan ala aswaja bisa masuk ke berbagai sendi kehidupan. Sehingga, pada sisi praksisnya pendidikan ala ASWAJA ini setidaknya bisa dilaksanakan dengan berbagai metode. Metode ini bisa diterapkan dengan aneka tekhnis sesuai dengan kebutuhan dimana metode diberlakukan.

Pendidikan karakter ala aswaja ini bertujuan mencetak pribadi yang berarakter berbudi luhur. Ruh dari pendidikan karakter ini pada prinsipnya untuk mengarahkan anak didik menjadi insan yang berguna bagi yang lain (khairunnas anf'auhum linnas).

Konsepsi Pendidikan Karakter yang ada ini hanya sebatas teori. Dalam ajaran agama, niat harus diiringi dengan perbuatan. Menanamkan karakter ala ASWAJA ini tidak bisa menghasilkan uot put yang diinginkan tanpa ada kegiatan aktif dan berkesinambungan. Sebagainya strategi dalam pengembangan disiplin keilmuan, maka pendidikan karakter berbasis nilai Ahlussunnah Wal Jamaah ini memerlukan strategi jitu agar bisa berdampak positif terhadap anak didik. Penanaman nilai ini bisa dilakukan di lembaga pendidikan, keluarga dan lingkungan dimana anak didik berada. Salah satu contoh strategi yang mungkin bisa dilakukan:

\begin{tabular}{|c|c|c|c|}
\hline Nilai & Strategi & Penerapan & Evaluasi \\
\hline $\begin{array}{l}\text { I'tidal/ta'adul } \\
\text { (Adil/Keadila } \\
\text { n) } \\
\text { Tasamuh } \\
\text { (Toleransi) } \\
\\
\text { Tawazun } \\
\text { (Seimbang) }\end{array}$ & $\begin{array}{l}\text { Diskusi/ } \\
\text { Problem } \\
\text { Solving }\end{array}$ & $\begin{array}{l}\text { Guru } \\
\text { menyediakan } \\
\text { topik } \\
\text { pembahasan. } \\
\text { Misalkan, guru } \\
\text { mengambil contoh } \\
\text { kasus yang } \\
\text { bernuansa tidak } \\
\text { adil }\end{array}$ & $\begin{array}{llr}\text { Guru bisa } & \text { melihat } \\
\text { apakah hasil praktek } \\
\text { yang dilakukan bisa } \\
\text { memberikan dampak } \\
\text { postif kepada anak } \\
\text { didik. } \\
\text { semacam ini } r \text { terus } \\
\text { dilakukan } \\
\text { akhirnya, target yang } \\
\text { diinginkan } & & \text { bisa } \\
\text { tercapai. } & \end{array}$ \\
\hline
\end{tabular}

Sementara ruang lingkup pendidikan karakter meliputi tiga spek, yaitu aspek kognitif, afektif dan psikomotor. Dalam realisasinya semua aspek tersebut memiliki ruang lingkup yang berisi nilai-nilai karakter. Penjelasan ruang lingkup ini sederhanya bisa dijabarkan dalam bagan berikut: 


\begin{tabular}{|l|l|}
\hline $\begin{array}{l}\text { Olah Pikir } \\
\text { (Cerdas, kreatif, inovatif dan Produktif) }\end{array}$ & $\begin{array}{l}\text { Olah hati } \\
\text { (Beriman, bertakwa, Jujur, Amanah, } \\
\text { tawakkal, berani mengambil resiko } \\
\text { dalam hal amar ma'ruf dan nahi mungkar) }\end{array}$ \\
\hline $\begin{array}{l}\text { Olah Fisik } \\
\text { (Bersih, Sehat, Sportif, Disiplin, } \\
\text { Kooperatif, suka berteman dan ceria) }\end{array}$ & $\begin{array}{l}\text { Olah Rasa/ Karsa } \\
\text { (Ramah, Toleran, Suka membantu, dan } \\
\text { memiliki jiwa mau bekerja keras) }\end{array}$ \\
\hline
\end{tabular}

Penjabaran sederhana nilai luhur kaitannya dengan praktis di lapangan di atas bisa membantu menumbuhkan karakter baik dalam diri anak. Setidaknya, langkah ini menjadi sejumlah jalan alternatif mencari pemecahan masalah amoral yang sedang melanda generasi muda saat ini.

\section{Penutup}

Pendidikan karakter dengan pendekatan apapun tidak akan bedampak tanpa diiringi praktek yang mapan. Guru sebagai motivator dan mitra belajar anak didik akan menjadi penentu penerapan pendidikan karakter berbasis nilai aswaja ini. Maka, pendidikan karakter bebasis aswaja ini akan menjadi ruh bagi anak didik dalam menjalankan aktivitas kehidupannya. Penerapan pendidikan karakter keaswajaan ini bisa dipraktekkan dalam berbagai kesempatan sehingga, nilai-nilai yang dikuak dari prinsip keaswajaan bisa menjadi 'mendarah daging' bagi anak didik.

Akhirnya, semua pendidikan karakter Ke-ASWAJA-an ini bisa menjadi jawaban dari kebimbangan arah dan ciri khas pendidikan saat ini. Sehingga, pendidikan di Indonesia bisa menemukan wajah yang sebenarnya. Amin. 


\section{DAFTAR PUSTAKA}

Abdullah Idi, 1999, Pengembangan Kurikulum (Teori dan Praktik), Jakarta: Radar Jaya.

Arikunto, Suharsini, 1996Pengelolaan Kelas dan Siswa, Jakarya: PT Raja Grafindo Persada.

Dimyati, 1999, Belajar dan Pembelajaran, Jakarta: Dirjen Dikti Depdikbud.

Devis, E., 1990, Teachers as Curiculum Evaluation, George Allen dan Unwin, Australia:

Hamalik, Omar, 1990, Pengembangan Kurikulum: Dasar-Dasar dan Perkembangannya, Bandung: Mandar Maju.

Hamilton, David, 1977, Curricullum Evaluation, Boston: Open Books Publishing Ltd.

Jalaluddin \& Usman Said, 1994, Filsafat Pendidikan Islam: Konsep dan Perkembangan Pemikirannya, Jakarta: PT. Raja Grafindo.

John P Miller, Seller Wayne, 1985, Curicullum Perpsektif and Praktice, London: Longman.

Maryanto, A., 1994, Kurikulum Lintas Bidang Study, Jakarta: Grasindo.

Muhaimin, 1991, Konsep Pendidikan Islam, Solo: Ramadhani.

Sardiman, A.M, 1990, Interaksi dan Motivasi Belajar Mengajar, Jakarta: Rajawali Persada.

Syah, Muhibbin, 2006, Psikologi Belajar, Jakarta: PT Raja Grafindo.

Subandijah., 1933, Pengembangan dan Inovasi Kurikulum, Jakarta: PT. Raja Grafindo Persada. 